\title{
Designing spawning closures can be complicated: Experience from cod in the Baltic
} Sea

Eero, Margit; Hinrichsen, Hans-Harald; Hjelm, Joakim; Huwer, Bastian; Hüssy, Karin; Köster, Friedrich W.; Margonski, Piotr; Plikshs, Maris; Storr-Paulsen, Marie; Zimmermann, Christopher

\section{Published in:}

Ocean \& Coastal Management

Link to article, DOI:

10.1016/j.ocecoaman.2018.12.018

Publication date:

2019

Document Version

Peer reviewed version

Link back to DTU Orbit

\section{Citation $(A P A)$ :}

Eero, M., Hinrichsen, H-H., Hjelm, J., Huwer, B., Hüssy, K., Köster, F. W., Margonski, P., Plikshs, M., StorrPaulsen, M., \& Zimmermann, C. (2019). Designing spawning closures can be complicated: Experience from cod in the Baltic Sea. Ocean \& Coastal Management, 169, 129-136.

https://doi.org/10.1016/j.ocecoaman.2018.12.018

\section{General rights}

Copyright and moral rights for the publications made accessible in the public portal are retained by the authors and/or other copyright owners and it is a condition of accessing publications that users recognise and abide by the legal requirements associated with these rights.

- Users may download and print one copy of any publication from the public portal for the purpose of private study or research.

- You may not further distribute the material or use it for any profit-making activity or commercial gain

- You may freely distribute the URL identifying the publication in the public portal 
1 Designing spawning closures can be complicated: experience from cod in the Baltic Sea

2 Margit Eero $^{1 *}$, Hans-Harald Hinrichsen ${ }^{2}$, Joakim Hjelm ${ }^{3}$, Bastian Huwer ${ }^{1}$, Karin Hüssy ${ }^{1}$,

3 Friedrich W. Köster ${ }^{1}$, Piotr Margonski ${ }^{4}$, Maris Plikshs ${ }^{5}$, Marie Storr-Paulsen ${ }^{1}$, Christopher

4 Zimmermann $^{6}$

$5 \quad{ }^{1}$ Technical University of Denmark, National Institute for Aquatic Resources, Kemitorvet

$6 \quad$ 202, DK-2800 Kgs. Lyngby, Denmark

$7 \quad{ }^{2}$ GEOMAR Helmholtz Centre for Ocean Research Kiel, Düsternbrooker Weg 20, 24105 Kiel,

8 Germany

$9 \quad{ }^{3}$ Swedish University of Agricultural Sciences, Department of Aquatic Resources, Institute of Marine

10 Research, 45330 Lysekil, Sweden

$11{ }^{4}$ National Marine Fisheries Research Institute, Kollataja 1,81-332 Gdynia, Poland

$12{ }^{5}$ Institute of Food Safety, Animal Health and Environment, Fish Resources Research Department,

13 Daugavgrivas 8, LV-1048 Riga, Latvia

$14 \quad{ }^{6}$ Thünen Institute of Baltic Sea Fisheries, Alter Hafen Süd 2, DE-18069 Rostock, Germany

15 *Corresponding author: tel: +45 3588 3318; fax: +45 3588 3333; email: mee@aqua.dtu.dk

17 Abstract

18 Fisheries management measures often include spatio-temporal closures during the spawning 19 period of the fish with an overarching aim of improving the stock status. The different 20 mechanisms how a spawning closure potentially can influence the stock are often not 21 explicitly considered when designing such closures. In this paper, we review and synthesize 22 the available data and knowledge on potential effects of the implemented spawning closures 23 on cod in the Baltic Sea. The Baltic cod example represents a relatively data rich case, which 24 allows demonstrating how a closure might affect different parameters of stock status via 25 different mechanisms, including potential unintended negative effects. We conclude that 26 designing relatively small area closures appropriately is highly complex and data demanding, 27 and may involve tradeoffs between positive and negative impacts on the stock. Seasonal 
28 closures covering most of the stock distribution during the spawning time are more robust to 29 data limitations, and less likely to be counterproductive if suboptimally designed.

30

31 Key words: spawning closure, fisheries management, recruitment, stock structure, Baltic cod 32 


\section{Introduction}

34 Fisheries management measures frequently include spatio-temporal closures as a supplement 35 to catch or effort limitations and gear regulations (Murawski et al., 2000; Roberts et al., 36 2005). The Marine Protected Area (MPA) type of closures, where fishing activities are 37 restricted or forbidden all year round generally have a wider aim of preserving biodiversity and meeting various nature conservation objectives (Halpern, 2003; Lester et al., 2009). To enhance a particular fish stock, seasonal closures during the spawning time of the population in concern are often used, the so-called spawning closures. There are numerous studies and ongoing debates on the effects of MPAs (e.g., Pendleton et al., 2017), while spawning closures and related benefits to fish stocks have received comparatively less attention in the literature so far.

Spawning closures can reduce overall fishing mortality of target species, especially when these are forming large spawning aggregations (Russell et al., 2012; Grüss et al., 2014). In case of no targeted fishery for a particular stock, spawning closures could reduce bycatch (O'Keefe et al., 2014). For fish stocks, where the overall fishing mortality is regulated by other measures, such as total allowable catch (TAC), the benefits from spawning closures are suggested to include greater reproductive output, positive effects on stock structure and reduced evolutionary effects of fishing (van Overzee and Rijnsdorp, 2015 and references therein). However, such effects are often difficult to demonstrate convincingly, and are possibly case specific. Therefore, case specific monitoring and evaluation of the established closures are needed as part of a management process to allow for possible adaptations as well as communication of their effectiveness (Pomeroy et al., 2005).

In this paper, we synthesize the state-of-the-art scientific knowledge on possible effects of the established spawning closures on cod in the Baltic Sea. We are specifically interested in distinguishing between different mechanisms how a spawning closure potentially could affect the cod. The Baltic cod provides a relatively data rich example, allowing to identify tradeoffs that may be involved when a spawning closure affects various aspects of the stock status via 62 different mechanisms. Furthermore, different types of spawning closures are implemented in 63 the Baltic Sea. Therefore, the Baltic cod example allows us addressing their relative advantages, especially in situations when scientific knowledge is limited, which may partly be 
the case even for stocks generally considered as data-rich. The present study is intended to guide future monitoring and research efforts as well as inform debates and decisions on the design and use of spawning closures in fisheries management in the Baltic Sea and elsewhere.

\section{Background of cod stocks and fisheries management measures in the Baltic Sea}

There are two genetically distinct populations of cod (Gahus morhua) in the Baltic Sea, eastern (EB) and western (WB) (Nielsen et al., 2003; 2005). Since 2004, these are managed in two separate areas, corresponding to the International Council for the Exploration of the Sea (ICES) Subdivisions (SD) 25-32 and 22-24, respectively (Fig. 1). Both the EB and WB cod occur in SD 24 (Hüssy et al., 2016). Cod in the Baltic Sea is a target species for fisheries with demersal trawls and gill-nets, and managed by total allowable catch (TAC). Technical measures including various regulations on fishing gears and a minimum conservation reference size are in place.

The EB cod biomass was record high in the 1970s-1980s, after which it substantially declined due to a combination of unfavourable environmental conditions for reproduction and a high fishing pressure (Bagge et al., 1994). In recent decade, fishing mortality is estimated substantially lower, though is presently considered still above the management target and the stock size has declined after a small recovery observed in the late 2000s (ICES, 2018a). The fishing mortality of WB cod is estimated well above the management target in the entire time series and the spawner biomass has been below the reference level since 2009, though is predicted to increase in coming years (ICES, 2018a).

In 1995, a few years after the major decline of the EB cod stock in the late 1980s, a prohibition to fish cod from June to August in the EB Sea was introduced (IBSFC, 1994). In 1998, additionally an area closure for all fishing activities was established in the essential cod spawning area in the Bornholm Basin (BB) (Fig. 1) in the period from mid-May to the end of August. In the following decade, the timing of these closures as well as the size and shape of the area closure in the BB were modified several times. These changes were not based on a well-defined biological mechanism and it is unclear how these closures were expected to contribute to rebuilding of the stock (Suuronen et al., 2010). In 2006, additional area closures were established in the Gdansk Deep (GD) and Gotland Basin (GB) (Fig. 1). In the first EU 
116

management plan for cod (EU, 2007), effort limitation in the EB Sea included a prohibition of all cod fisheries from July 1 to August 31, from here on referred to as a seasonal closure. Additionally, the plan included a prohibition of any fishing activities in the three designated areas (Fig. 1) from May 1 to October 31, which are referred to as area closures. In the WB Sea, a seasonal closure was in effect from April 1 to 30. In the new EU Baltic multi-annual management plan (Baltic MAP) (EU, 2016), seasonal closures in both the EB and WB Sea were lifted, while the area closures in the EB Sea were maintained (Table 1). According to the Baltic MAP, supplementary measures need to be applied when the stocks are in poor state, which can include spawning closures (EU, 2016). In practice, a seasonal closure from February 15 to March 31 was implemented in the WB Sea in 2016, further extended to February 1- March 31 in 2017-2018 (Table 1). In the EB Sea, a seasonal closure in SDs 2526 was re-introduced for 2018. There are exemptions in place for vessels $<15 \mathrm{~m}$ (in 2017 in WB) or $<12 \mathrm{~m}$ (in 2018 in EB and WB) if they can demonstrate that they do not fish for cod in areas deeper than $20 \mathrm{~m}$.

Table 1. Overview of the seasonal (SC) and area closures $(A C)$ for cod fisheries enforced in the Eastern Baltic (EB) and Western Baltic (WB) management areas under the present EU management plan (EU, 2016). See Fig. 1 for location of the area closures in Bornholm Basin (BB), Gdansk Deep (GD) and Gotland Basin (GB).

\begin{tabular}{ll}
\hline EB management area & WB management area \\
\hline 2016-2018: & $2016:$ \\
AC: May 1-October 31 (BB, GD, GB) & SC: February 15-March 31 (SD 22-24) \\
2018: & 2017-2018: \\
SC: July1-August 31 (SDs 25-26) & SC: February 1-March 31 (SD 22-24)
\end{tabular}

117

3. Material and Methods

119

120

\subsection{Defining potential objectives for the cod spawning closures in the Baltic Sea}

121 The overarching aim of the cod spawning closures in the Baltic Sea is improving the stock 122 status. The legislations do not specify further, which parameters of stock status the closures 123 are intended to improve, and through which mechanisms. According to the literature, potential 
benefits of spawning closures as a supplementary management measure can include greater reproductive output, positive effects on stock structure, reduced evolutionary effects of fishing and reduced impact on spawning habitat (e.g. van Overzee and Rijnsdorp, 2015 and references therein). We focused our analyses on the potential effects of the spawning closures on cod recruitment, distinguishing between three different mechanisms. These included direct effects of the closures on:

i) the quantity and quality of egg production by ensuring undisturbed spawning activity;

ii) preserving the spawners whose offspring have a higher survival probability;

iii) increasing the proportion of larger/older individuals in the stock.

Further explanation of how the cod recruitment could benefit from these potential effects of spawning closures is provided in section 4 . We focus on these selected potential effects of the closures because of their relevance for the Baltic cod and the availability of scientific information, which allows for their relatively in-depth consideration. Hence, improving cod recruitment through the three mechanisms described above was used as a specific objective for the Baltic cod spawning closures in this study.

Concerning other potential benefits of spawning closures suggested in the literature, such as avoiding evolutionary change towards earlier maturation or reducing the risk of losing genetic diversity (van Overzee and Rijnsdorp, 2015), little information is available for Baltic cod. Size at maturation of the EB cod has substantially declined from the late 1990s to 2010 s (Köster et al., 2017), when spawning closures have been enforced. This change is not fully understood, though is not considered to be connected to the spawning closures, which should have an opposite effect, i.e. preventing earlier maturation. Both the EB and WB cod have different spawning locations in the Baltic Sea, however genetic differences between those within a stock have not been demonstrated (Nielsen et al., 2003; 2005; Poćwierz-Kotus et al., 2015). Spawning site fidelity on a finer spatial scale occurs in some cod stocks (e.g., Zemekis et al., 2014). Such aspects as well as related potential impacts of spawning closures are largely unknown for Baltic cod. 
166

167

168

169

170

171

172

173

174

175

176

177

178

179

180

181

182

183

184

185

186

\subsection{Evaluation approach}

The effects of spawning closures on wild fish stocks are generally very difficult to demonstrate or quantify (e.g., Arendse et al., 2007; Clarke et al., 2015). This is because of a large number of factors and processes influencing fish stock dynamics, for example recruitment, including that of cod in the Baltic Sea (Köster et al., 2017). The approach of looking at stock parameters before and after the implementation of closures is frequently applied (e.g., Russ et al., 2004; Torres-Irineo et al., 2011), however is challenged by other factors influencing the stock dynamics at the same time (Davies et al., 2017). Comparable control areas or seasons are often not available or meaningful, which is also the case for cod in the Baltic Sea.

Recognizing this general difficulty in assessing the realized effects of spawning closures, we took a different approach in this study, where we instead evaluated their potential effects. In this approach, we focused on identifying whether or not there is an overlap between the closure and the stock component intended to be protected, in time and space. If such overlap is lacking, the closure can impossibly be beneficial. If the overlap is present, this implies that the closure can potentially contribute to improving the stock status through a certain mechanism. Corresponding to the three potential effects of the spawning closures we address in this paper, we evaluated whether there is an overlap between

- the closures and the cod spawning activity,

- the closures and the spawners whose offspring has a higher survival probability,

- the closures and the largest/oldest cod.

We evaluated potential both positive and negative effects of the closures. The latter were associated with the possibility of fishing effort reallocation during the time of closure, compromising some aspects of the stock status. Both the area and seasonal closures enforced under the present EU management plan (EU, 2016) were considered (Table 1), separately for the EB and WB management areas. Our study does not cover the economic and social implications, or other possible ecological effects of the closures on other species or habitats.

\subsection{Data}


187 A number of scientific publications over the past decades have addressed cod recruitment in 188 the Baltic Sea, including aspects relevant for evaluating the spawning closures. This paper presents a synthesis of these findings in the context of the specific questions regarding the potential effects of the spawning closures, defined in the sections above. This review is supplemented by additional analyses, using data on egg abundances from ichthyoplankton surveys and cod catch information from the Baltic fish stock Assessment Working Group in ICES (ICES, 2018a). For the EB cod, part of the present synthesis was conducted in connection with a workshop in ICES (2018b).

\section{Results}

\subsection{Undisturbed spawning}

Fishing activities may adversely affect the spawning fish and subsequently the quantity or quality of the offspring (Sadovy de Mitcheson and Erisman, 2012). The disturbance can take place via a number of mechanisms, including noise from fishing and interruption of spawning, causing physiological stress response in the fish and disturbance of natural spawning behaviour (van Overzee and Rijnsdorp, 2015). The effect of spawning disturbance on reproductive output is very difficult to demonstrate or quantify for wild fish stocks, and no such investigations are available for Baltic cod. A pre-requisite for a closure to ensure undisturbed spawning is a spatio-temporal overlap with spawning activity, which is the only aspect in relation to spawning disturbance that can presently be evaluated for Baltic cod.

EB: In the EB Sea, there are historically three main cod spawning grounds, in deeper areas of the Bornholm Basin (BB), Gdansk Deep (GD) and Gotland Basin (GB) (Fig. 1). Due to reduced salinity and oxygen, conditions for cod egg survival in GD and GB have deteriorated considerably since the mid-1980s (MacKenzie et al., 2000; Köster et al., 2009), and these spawning areas have presently a limited contribution to cod recruitment (Plikshs et al., 2015; Köster et al., 2017). Therefore, disturbance from fishing in these areas unlikely has a measurable effect on the reproductive output of the stock. In the BB, i.e. presently the main spawning ground for the EB cod, spawning is restricted to areas with water depth $>60 \mathrm{~m}$ (Wieland, 1988; Hinrichsen et al., 2007; Figure 2a). The horizontal distribution of eggs within the spawning area varies between years as well as within a year (Hinrichsen et al., 2007; 
218 Neumann et al., 2014; Fig. S1). Thus, the area closure in the BB covers varying proportions

219 of the spawning activity, while not covering the entire spawning area.

220

221 The spawning of the EB cod starts in February-March and last until October-November 222 (Wieland et al., 2000). Peak spawning occurred between the end of April and mid-June in the 223 1970s and 1980s (MacKenzie et al., 1996), and gradually changed to the second half of July 224 during the 1990s (Wieland et al., 2000). In the late 2000s, the main spawning expanded to 225 spring, covering a 4 months period from May to August (Neumann et al., 2014; Köster et al., 226 2017). In most years since 2010, highest egg abundances have been recorded in June (ICES, $2272018 b$ ), which is not covered by the seasonal closure enforced in July-August.

228

229

WB: WB cod spawn in areas deeper than $20 \mathrm{~m}$ in Kiel Bay, Mecklenburg Bay, and the 230 Danish Belts (SD 22; Fig. 1) (Bleil and Oeberst, 2002; Hüssy, 2011). Cod spawning activities are also recorded in the Sound (SD 23) (Hüssy, 2011). Both the WB and EB cod spawn in the Arkona Basin (AB) (in SD 24) (Bleil et al., 2009; Hüssy, 2011), in areas with water depth $>40$ m (Fig. 1) (Bleil and Oeberst, 2002). The main spawning period of female repeat spawning cod in SD 22 (the core spawning area of the WB stock) is from mid-February to early April, matching the timing of the seasonal closure implemented in this area in 2016-2018 (STECF, 2016). In the $A B$, the timing of cod spawning reflects a combination of different spawning times of the WB and EB stock, which are mixed in the area.

238

239

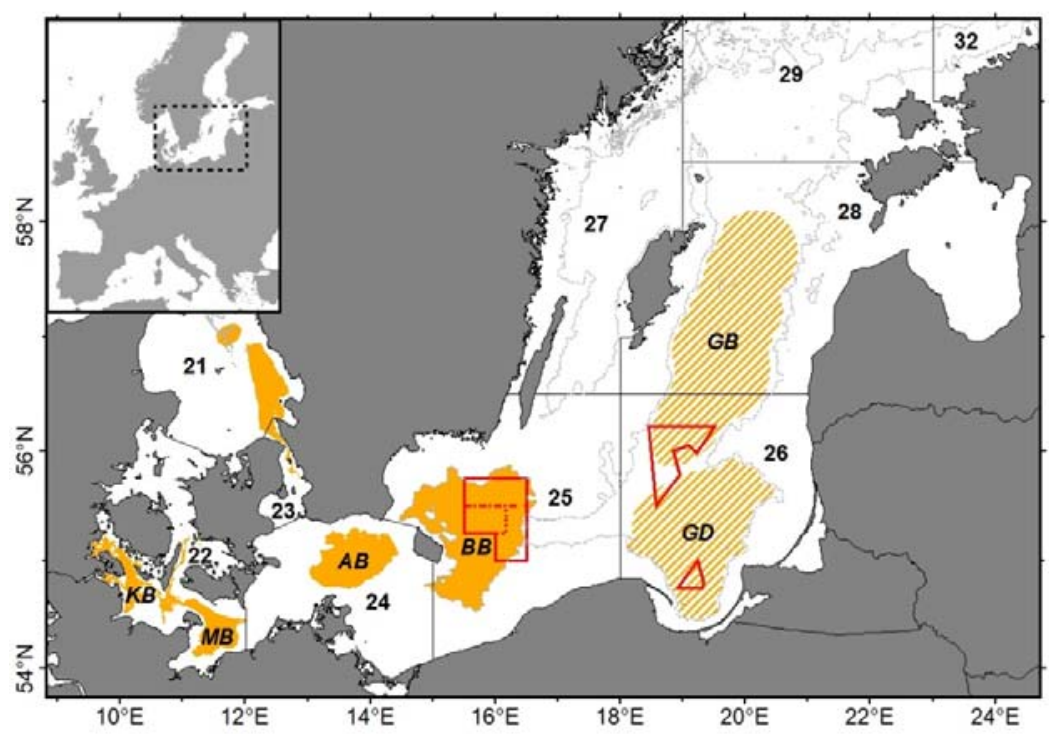


240 Fig. 1. Cod spawning areas (filled areas on the map) in the Baltic Sea in the Sound (23), Kiel

241 Bay (KB), Mecklenburg Bay (MB), Arkona Basin (AB) and Bornholm Basin (BB); the

242 shaded areas in Gdansk Deep (GD) and Gotland Basin (GB) indicate spawning areas that

243 have had limited contribution to cod recruitment since the mid-1980s (modified from Bagge

244 et al., 1994 and Hüssy, 2011). The bold lines show the borders of the present area closures in

245 the eastern Baltic Sea (EU, 2016), with the broken lines indicating historical borders for the

246 closure in BB. The numbers and thin lines depict the ICES Subdivisions (SD).

247

\subsection{Early life stage survival}

249

The effect of undisturbed spawning on reproductive output needs to be seen in conjunction

250 with survival probability of the offspring, as high egg production alone is not sufficient for enhancing recruitment. If the survival of early life stages is variable in time and space, spawning closures could potentially enhance the recruitment by protecting those spawners whose offspring has a higher survival probability.

EB: The survival of cod eggs in the GD and GB has been low since the 1990s, due to unfavourable salinity and oxygen conditions (Köster et al., 2017). Therefore, we focus this section on the $\mathrm{BB}$, where hydrographic conditions generally support relatively high egg survival in the months and areas covered by both the seasonal and area closure. However, the closures do not cover the entire window of high egg survival probability. Modelling of egg survival has shown that, on average, the highest concentrations of surviving eggs originate from the center of the basin (Fig. 2b), with the highest survival probability in May-August

The survival of first feeding larvae, which is critical for determining recruitment success of the EB cod (Köster et al., 2005; Huwer et al., 2011) is largely affected by prey availability, in particular Pseudocalanus nauplii (Hinrichsen et al., 2002; Voss et al., 2003). A modelling study suggests that, at favourable feeding conditions, larval survival is highest in the center of the basin (Hinrichsen et al., 2002), i.e. including the area closure in the BB. In contrast, in

269 years with low Pseudocalanus abundance, larvae have better feeding opportunities and a 270 higher survival probability if retained at the slopes of the basin or transported into shallower coastal regions, i.e. outside the area closure (Hinrichsen et al., 2002). This modelling result 
was confirmed by an empirical study back-tracking hatch positions of pelagic juvenile survivors in year 2000, which revealed that the vast majority of these juveniles originated from the slopes of the BB, i.e. outside the closed area (Huwer et al., 2014; Fig. 2c). It should be noted that the absolute numbers of recruits originating from different time windows or locations have not been quantified, as this would require more extensive and systematic sampling of juveniles than is currently the case.
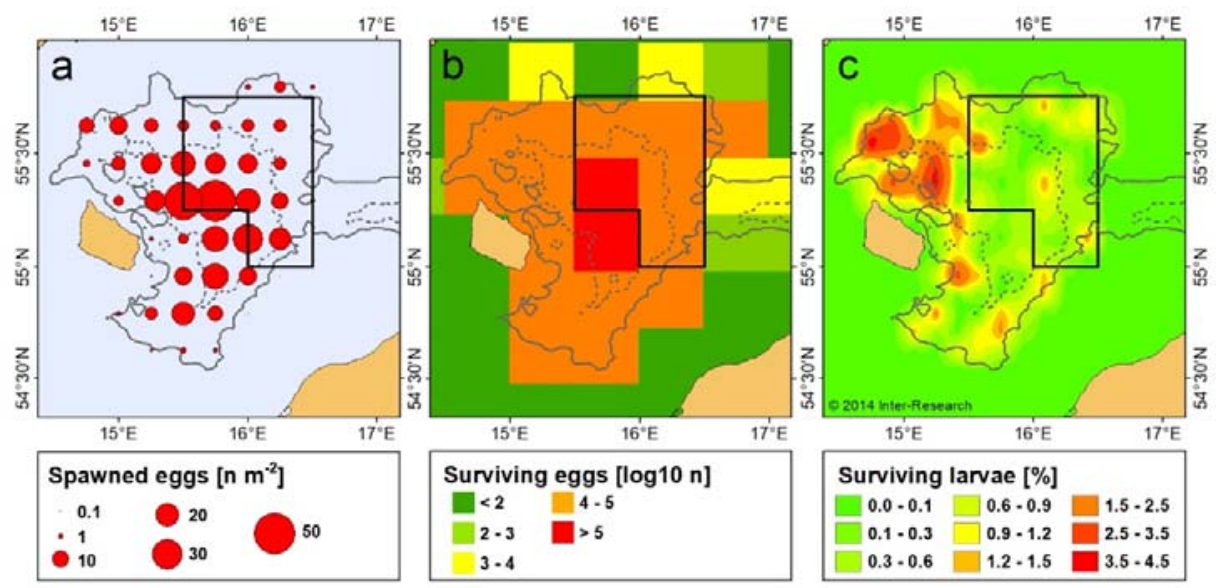

Fig. 2. EB cod in the Bornholm Basin: (a) Horizontal distribution of newly spawned cod eggs (stage 1A), representing the location of spawning activity (average for the years 1989-2003, from Hinrichsen et al., 2007). (b) Modelled spatial origin of first-feeding yolk-sac larvae that have survived through the egg stage (average in 1971-2010, from Hinrichsen et al., 2016a). (c) Spatial origin of pelagic juveniles that have survived through the larval stage, (example for the year 2000, from Huwer et al., 2014). The grey lines show $60 \mathrm{~m}$ (solid) and $80 \mathrm{~m}$ (dashed) depth contours. The black solid box shows the extent of the present area closure (EU, 2016).

WB: The survival of WB cod eggs is affected by temperature (see Hüssy 2011 for review), which is more likely to be below the optimum (in the range of $4-8{ }^{\circ} \mathrm{C}$ ) early in the spawning season, including the time of the present closure. However, no clear relation between temperature and year-class strength suggests that other factors are likely more important for determining recruitment success (Hüssy et al., 2012). The egg quality (size, fertilization success) as well as the number of eggs per batch decrease towards the end of spawning of an individual cod (Bleil and Oeberst, 1998; Vallin and Nissling, 2000). Thus, the eggs with the best quality characteristics, which may influence their survival probability, are released within 
the period covered by the closures in 2016-2018. In terms of the spatial coverage, a closure in SD 24 has likely a limited contribution to enhancing the WB cod recruitment. This is due to generally low egg survival in this area related to cold winter water filling the basin during the main spawning time of the WB cod (Köster et al., 2017). During the 2000s, the environmental conditions for reproduction in the $\mathrm{AB}$ were generally more favourable for the $\mathrm{EB}$ than for the WB cod (Köster et al., 2017), with best spawning conditions irregularly occurring from midMay to end-June (STECF, 2010; Hüssy et al., 2016).

\subsection{Size/age structure of cod catches}

Larger female cod produce higher number of eggs, and there is evidence for increased offspring quality with parent age or reproductive experience (e.g., Marteinsdottir and Steinarsson, 1998; Trippel, 1998). Moreover, the on average larger eggs of larger cod are neutrally buoyant at a lower salinity, implying that the eggs from older/larger EB cod have a greater survival probability under low salinity conditions (Vallin and Nissling 2000; Hinrichsen et al., 2016b). The size distribution of the EB cod stock has truncated in later years, with very few larger individuals in the stock (ICES, 2018a). Thus, protecting the remaining relatively larger cod may be essentially important. If fisheries catches during the spawning time contain a larger fraction of older/larger individuals than in other times of the year, a spawning closure could be beneficial for the recruitment success by preserving larger cod. When investigating this hypothesis, we assumed that the total annual catch amount is unchanged regardless of the closures and we only focused on the potential effect of the closures on the size/age structure of the catch.

EB: Data on the amount and size structure of cod landings are available by quarter (q) and ICES SDs in the Baltic Sea. Age information in not available for the EB cod for later years. Seasonally, the fraction of the larger $(>45 \mathrm{~cm})$ EB cod in fisheries catch has generally been highest in q3, although similar to q4 (Fig. 3a). However, the amount of cod landings in $\mathrm{q} 3$ has been relatively low throughout the time series, i.e. including the years before the implementation of the seasonal closure in 1995 (Fig. S2). This is likely due to low incentives for cod fishery in this time of the year, regardless of the closure. Thus, the seasonal summer 
341 available on a SD level.

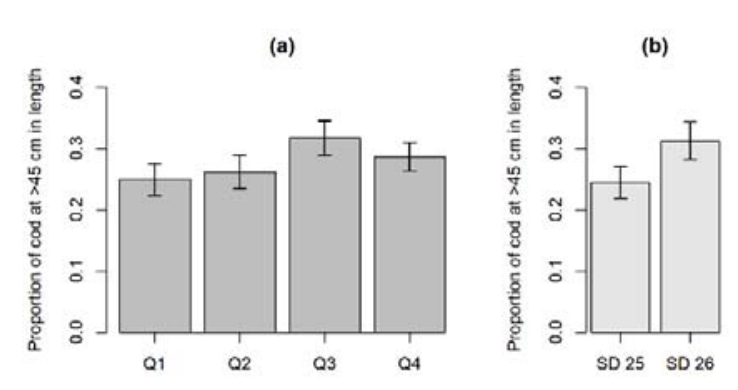

closure may to some extent reduce the fraction of the largest individuals in fisheries catch, though the effect is likely not substantial.

Spatially, the catches in SD 26 include a higher proportion of larger cod compared to SD 25 (Fig. 3b). There is some variability in this pattern between quarters (Fig. S3). However, the fraction of the largest cod in fisheries catch in the main spawning area (in SD 25) does not seem to be higher in any time of the year. The importance of SD 26 in total EB cod landings has substantially increased in later years (Fig. S4), in line with the relatively larger cod found in this area, making it more attractive for the fisheries. Finer scale spatial data on the distribution of different size-groups of cod within a SD during the time of the closures are not available. This is because research surveys are conducted in the $1^{\text {st }}$ and $4^{\text {th }}$ quarters, i.e. outside the main spawning time, and data on size composition of the fisheries catch are only

Fig. 3. Average proportion of larger eastern Baltic cod $(>45 \mathrm{~cm}$ in length) in the commercial catch (a) by quarter and (b) in SDs 25 and 26 (annual average). The error bars represent standard error of the mean, calculated over the years 2001-2017.

WB: The proportion of older WB cod in fisheries landings has been highest during the main spawning season in $\mathrm{q} 1$, although similar to q2 (Fig. 4a). Thus, a fishery closure in q1 could potentially reduce the proportion of the largest cod in fisheries catch. However, despite the spawning closure being enforced in q1, a substantial share of the landings in 2016-2017 was still taken in the period when the highest fraction of older cod occurs in the landings, i.e. in the remainder of q1 and in q2 (Fig. 4b). This suggests that the spawning closure likely did not reduce the proportion of larger cod in fisheries catch in those years substantially. 

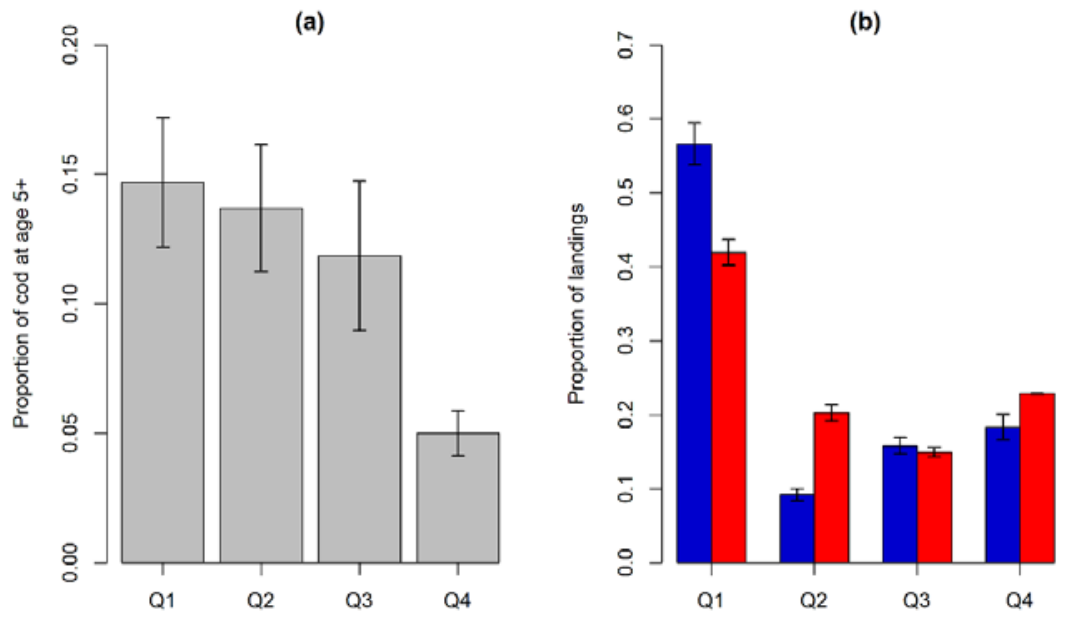

Figure 4. (a) Average proportion of cod at age 5+ in the landings of Western Baltic cod in ICES Subdivisions 22-23, by quarter (Q). The error bars represent standard error of the mean, calculated over the years 2005-2017. (b) Average relative distribution of cod landings between quarters in 2005-2015 (blue bars) compared to 2016-2017 (red bars). The distinction of the periods corresponds to revision of the time of the closure. Error bars show standard error of the mean.

\subsection{Possible tradeoffs between the different impacts of the spawning closures on cod}

The present area closure in the main spawning ground (BB) of the EB cod allows part of the stock to spawn undisturbed. However, this would not necessarily increase the recruitment, if the offspring spawned outside the closure would have a higher survival probability due to better environmental or feeding conditions. In such situations, the area closure may in fact increase disturbance and fishing pressure on those spawners whose offspring would otherwise have a greater chance to survive (Table 2). This is because fishing effort is likely to be concentrated in the areas outside the closure, as exemplified in Fig. 5. Expansion of the area closure to cover most of the spawning (defined by $60 \mathrm{~m}$ isobaths in BB) could avoid the potential negative effect of the closure in relation to offspring survival. However, an area closure in SD 25 could also cause fishing effort reallocation to SD 26, increasing the fishing pressure on the remaining larger cod found in this area, with negative impacts on stock structure. 
377 This example demonstrates that a spawning close that is beneficial for the stock through one 378 mechanism may at the same time compromise other aspects of the stock status. The relative 379 importance of these different impacts is presently not possible to quantify with the data and 380 knowledge available for the EB cod. The tradeoffs between different impacts are more likely 381 to occur when the closures cover small areas, causing fishing effort to concentrate on other stock components during the time of the closure. In the case of the EB cod, avoiding the potential negative effects of the area closure in BB we have identified in this study, the closure would need to cover most of the stock distribution, i.e. the entire spawning area in BB and also SD 26. The latter is because it is not possible to identify smaller areas where the largest cod occur, and these are unlikely to correspond to the present small area closures in SD 26, which are not designed for that purpose.

388

The seasonal closure (July 1-August 31) implemented in 2018 in the main cod distribution area (SD 25-26) does not cover the months of peak spawning (June) in recent years (ICES, 2018b). The closure in July-August may to some extent cause temporal fishing effort reallocation to June increasing the disturbance of peak spawning in this month. However, this could be avoided simply by adjusting the timing of the closure to cover peak spawning. For WB cod, where the investigated closures covered the entire distribution area of the stock and matched the peak spawning time, potential negative effects associated with the closures were not identified.

397

Table 2. Summary of the potential positive and negative effects of the implemented area closure $(A C)$ in Bornholm Basin (BB) and the seasonal closure (SC) in SDs 25-26 on the eastern Baltic cod.

\begin{tabular}{|l|l|l|}
\hline Closure & Potential positive effects & Potential negative effects \\
\hline AC: BB & Undisturbed spawning of a fraction \\
May 1-Oct 31 & $\begin{array}{l}\text { Part of the spawning, high survival of } \\
\text { offspring, and larger cod occur in areas } \\
\text { outside the closure, where fishing effort } \\
\text { may reallocate. }\end{array}$ \\
\hline $\begin{array}{l}\text { SC: July 1- } \\
\text { August 31(SDs } \\
\text { 25-26) }\end{array}$ & $\begin{array}{l}\text { Undisturbed spawning of a fraction } \\
\text { of the stock; somewhat reduced } \\
\text { fishing pressure on larger cod. }\end{array}$ & $\begin{array}{l}\text { Possibly increased disturbance of peak } \\
\text { spawning in June, due to temporal fishing } \\
\text { effort reallocation. }\end{array}$ \\
\hline
\end{tabular}



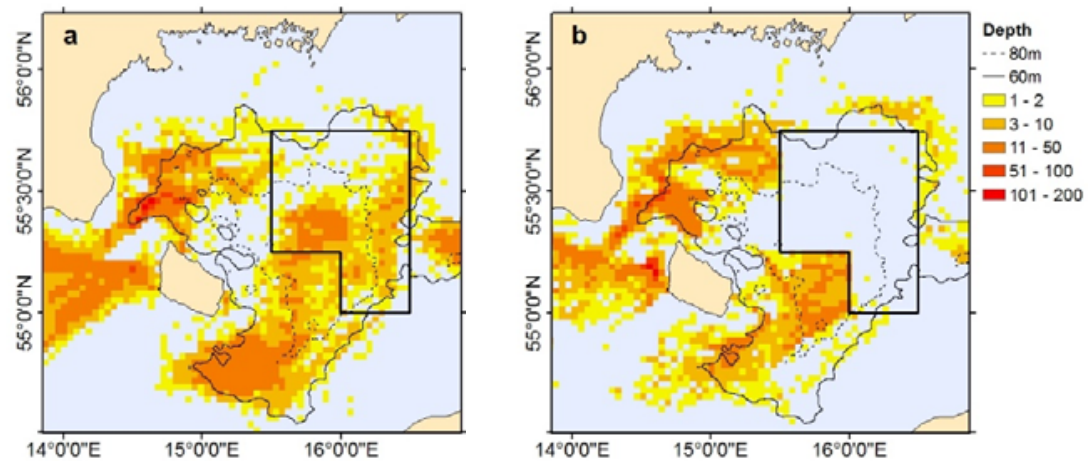

Fig. 5. Fishing effort in the Bornholm Basin: Example of the spatial distribution of fisheries in (a) months without the area closure (Nov-April) compared to (b) the months with the area closure in force (May-Oct). Based on Swedish and Danish VMS data for demersal fishing activities (defined by 2-4 knots speed), average for the years 2014-2016. The black solid box shows the extent of the area closure (EU, 2016).

\section{Discussion}

\subsection{Challenges associated with evaluating the effects of spawning closures}

Fishing closures during the spawning time of the fish are commonly applied in fisheries management worldwide, but their impacts on fish stock development are generally very difficult to demonstrate. Consequently, evaluations of the effectiveness of such closures have often remained inconclusive (e.g., Arendse et al., 2007; Clarke et al., 2015). Studies on closures in general have found that their effectiveness depends, amongst others, on their spatial and temporal properties considering the behavior and biology of the target species (Sheaves et al., 2006; van Overzee and Rijnsdorp, 2015). Size and age of the closure are important (Vandeperre et al., 2011) and what other fisheries management measures are applied in parallel (Beare et al., 2013; Clarke et al., 2015). Environmental and other influences often "mask" the effects of the closures on fish stocks complicating the evaluations of their effectiveness (Pastoors et al., 2000; Beare et al., 2013).

For the EB cod, the strongest year-classes occurred in the 1970s-early 1980s, i.e. prior to the implementation of the spawning closures, which was due to good environmental conditions in these years (Bagge et al., 1994). For the WB cod, both the strongest and the weakest yearclass in the last 20 years were formed in years when most spawning was protected by the 
closure (in 2016 and 2017) (ICES, 2018a). Although environmental and other factors

429

430

431

432

433

434

435

436

437

438

439

440

441

442

443

444

445

446

447

448

449

450

451

452 The main potential benefits of spawning closures suggested in the literature (e.g., van Overzee 453 and Rijnsdorp, 2015) include the aspects of undisturbed spawning, offspring survival and

determine major fluctuations in the Baltic cod recruitment, spawning closures may modify the recruitment possible to achieve under given ecosystem and environmental conditions. However, such effects have so far not been possible to disentangle.

Recognizing the difficulty to demonstrate or quantify the realized effects of spawning closures on fish stocks, we took a different approach in this study, where we investigated the potential effects of the spawning closures on Baltic cod. In this approach, we evaluated whether positive effects to the stock potentially can occur through specific mechanisms. This approach does not verify whether a closure actually has a measurable effect on the stock. Instead, it evaluates whether the design of the closure allows benefits to occur through a specific mechanism, under the assumption that such benefits exist. The choice of the mechanisms to consider in such evaluation depends at least partly on the specific objectives of the closure, which are often not formally defined. Past reviews have identified lack of clear, testable objectives as one of the basic obstacles for evaluating the effectiveness of the implemented closures (STECF, 2007; Beare et al., 2013). Therefore, the first task is often to define, based on knowledge and logic, some objectives for the closures that their effectiveness can then be evaluated against (STECF, 2007). In this paper, we did not use the overarching objective of improving the cod stock status as an evaluation criterion, because many other factors influence the stock development. Instead, we focused on the specific mechanisms through which the closures could potentially influence the cod stocks. This approach allows considering potential both positive and negative impacts of the closures, which may be important, even if not being part of the intended objectives of the closures. stock structure, which we addressed in this study. We considered these potential effects of the spawning closures most relevant for the Baltic cod. However, we do not exclude that other objectives could possibly be defined. For example, fishing closures can affect the total catch of the species, which is often most rigorously and quantitative analysed (e.g., Kraus et al., 2009; Clarke et al., 2015), in contrast to the other possible effects of the closures. STECF (2016) has recently evaluated the effects of the seasonal closures on the EB cod catch, 
suggesting that under the assumption of no effort reallocation, the closures could reduce the total fisheries catch of the EB cod. However, when TAC management is in place as for the

462 Baltic cod, this can deliver the desired total catch level more directly than a closure, given that

463 TACs are effective in regulating total catch. For that reason, we focused this paper on the 464 potential benefits of the spawning closures related to recruitment, which would be difficult to 465 achieve by quota management alone.

\subsection{Lessons from the Baltic cod case study}

In the Baltic Sea, ichthyoplankton surveys monitoring spatio-temporal dynamics of cod eggs and larvae (e.g., Hinrichsen et al., 2007) as well as studies on adult maturity (Bleil et al., 2009) provide information on when and where cod spawning takes place. Regular monitoring has demonstrated that the most intensive spawning activity is variable in time and space (Fig. S1), implying that closures covering relatively small areas or short time periods have a low chance of matching the peak spawning in all years. Furthermore, the EB cod is one of the fortunate examples, where substantial process knowledge and modelling tools to evaluate spatio-temporal variability in early life stage survival are available (Hinrichsen et al., 2002; ICES, 2004; Kraus et al., 2009; Huwer et al., 2014). These studies have demonstrated that the highest concentration of spawning activity is not always corresponding to the highest survival probability up to juvenile stage, further complicating the design of spawning closures covering relatively small areas.

In practice, it would likely be difficult to adjust the spawning closures to dynamic conditions (Hinrichsen et al., 2007). The presently available knowledge on cod early life stage production and survival in the Baltic Sea is a result of several decades of research efforts. This has allowed identifying issues that may be important in relation to spawning closures, 485 however not necessarily feasible to adjust to in real time. Such investigations are often time consuming and labour intensive, and therefore not regularly updated. Moreover, even in the relatively data rich case of the Baltic cod, a number of knowledge gaps still exist. For example, it is currently not possible to quantify the spatio-temporal origin of surviving recruits in absolute terms, or describe the fine scale spatial distribution of different stock components during the spawning time. Both of these questions are highly relevant especially

491 for designing smaller area closures. 
493 The data collection for fisheries management purposes generally focuses on traditional fish 494 stock assessments, which provide the biological basis for setting annual catch limits. As 495 spawning closures can potentially affect a fish stock through various complex mechanisms, 496 data requirements for their proper evaluation are much greater, including, for example 497 information on spawning behaviour and physiology of the fish (Morgan et al., 1999; Dean et 498 al., 2014). The information relevant for designing and evaluating spawning closures, if 499 existing, is mostly produced via scientific programs, which are generally decoupled from 500 management needs. This implies that the information is often insufficient, irregularly updated, or not tailored to the purpose of evaluating management measures such as spawning closures.

502

503 It is unclear whether monitoring and research on this topic can substantially increase in future.

504 Therefore, it is important to choose management measures, which are robust to data 505 limitations and related uncertainties. The Baltic cod example demonstrates that designing 506 smaller area closures properly is associated with much greater data requirements compared to 507 a closure covering most of the distribution area of the stock during its spawning time. This is 508 because small area closures cause fishing effort reallocation to other stock components with a 509 risk of unintended negative effects via the mechanisms that may not have been accounted for 510 when designing the closure. To avoid these counterproductive effects, a closure would need to 511 be sufficiently large. This is in line with experiences from other areas, suggesting that size is 512 an important feature of the closed areas in general (Edgar et al., 2014).

514 Quantifying the actual effects of spawning closures likely remains a challenge also in future. 515 Therefore, if spawning closures are chosen to be applied as a supplementary management 516 measure, these should be designed in a way that allows their potential benefits to occur, while 517 avoiding potential counteracting effects. The Baltic cod example suggests that the closures 518 covering most of the distribution area of the stock during its peak spawning time are better 519 suited for this purpose rather than those covering small areas.

\section{Conclusions}


523 The example of cod in the Baltic Sea illustrates the complexity of considerations that may be 524 involved in designing an appropriate spawning closure to improve fish stock status. A closure 525 and the resulting fishing effort reallocation can potentially affect the stock via a number of 526 mechanisms, which can include unintended negative effects counteracting the expected 527 benefits of the closure. Proper evaluation of the different mechanisms how a closure can 528 affect the stock has high demands for data and biological knowledge, which may not be 529 present even in data-rich cases such as the Baltic cod. Among the two types of closures we 530 have investigated, the design of smaller area closures generally involves greater complexity 531 and data requirements compared to the closures covering most of the distribution area of the stock during the spawning time. Also, smaller area closures are associated with a higher risk of having negative effects to the stock, if not rigorously assessed and adapted to changing conditions. The spawning closures covering most of the distribution area of the stock are generally more robust to the uncertainties and gaps in biological knowledge.

\section{Acknowledgements}

The present study was funded by the European Maritime and Fisheries Fund and the Danish 540 Fisheries Agency and contributes to BONUS projects, the joint Baltic Sea research and development programme (Art 185), funded jointly from the European Union's Seventh Programme for research, technological development, and demonstration and from national funding institutions (BIO-C3 and INSPIRE). We thank the participants of the ICES workshop to evaluate the effect of conservation measures on Eastern Baltic cod (WKCONGA) that inspired this paper. We also thank Patrik Jonsson for assistance with the VMS data, and Clara

546 Ulrich and the three anonymous reviews for valuable comments on earlier versions of the 547 manuscript.

549 Supplementary data

Supplementary information is available at the online version of the article.

\section{References}


Arendse, C. J., Govender, A., and Branch, G. M. 2007. Are closed fishing seasons an effective means of increasing reproductive output? A per-recruit simulation using the limpet Cymbula granatina as a case history. Fisheries Research, 85: 93-100.

Bagge, O., Thurow, F., Steffensen, E., and Bay, J. 1994. The Baltic cod. Dana, 10: 1-28.

Beare, D., Rijnsdorp, A. D., Blaesberg, M., Damm, U., Egekvist, J., Fock, H., Kloppmann, M., et al. 2013. Evaluating the effect of fishery closures: Lessons learnt from the Plaice Box. Journal of Sea Research, 84: 49-60.

Bleil, M., and Oeberst, R. 1998. The spawning of cod (Gadus morhua morhua) under controlled conditions of captivity, quantity and quality of spawned eggs. ICES Document CM 1998/ DD: 3, 27 pp.

Bleil, M., and Oeberst, R. 2002. Spawning areas of the cod stock in the western Baltic Sea and minimum length at maturity. Archive of Fishery and Marine Research, 49: 243-258.

Bleil, M., Oeberst, R., and Urrutia, P. 2009. Seasonal maturity development of Baltic cod in different spawning areas: importance of the Arkona Sea for the summer spawning stock. Journal of Applied Ichthyology, 25: 10-17.

Clarke, J., Bailey, D. M., and Wright, P. J. 2015. Evaluating the effectiveness of a seasonal spawning area closure. ICES Journal of Marine Science, 72: 2627-2637.

Davies, T. K., Mees, C. C., and Milner-Gulland, E. J. 2017. Use of a counterfactual approach to evaluate the effect of area closures on fishing location in a tropical tuna fishery. PLoS ONE 12: e0174758.

Dean, M. J., Hoffman, W. S., Zemeckis, D. R., and Armstrong, M. P. 2014. Fine-scale diel and gender-based patterns in behaviour of Atlantic cod (Gadus morhua) on a spawning ground in the western Gulf of Maine. ICES Journal of Marine Science, 71: 1474-1489.

Edgar, G. J., Stuart-Smith, R. D., Willis, T. J., Kininmonth, S., Baker, S. C., Banks, S., Barrett, N. S. et al. 2014. Global conservation outcomes depend on marine protected areas with five key features. Nature, 506: 216-220.

EU. 2007. Council Regulation (EC) No 1098/2007 of 18 September 2007 establishing a multiannual plan for the cod stocks in the Baltic Sea and the fisheries exploiting those stocks, amending Regulation (EEC) No 2847/93 and repealing Regulation (EC) No $779 / 97$.

EU. 2016. Regulation (EU) 2016/1139 of the European Parliament and of the Council of 6 July 2016 establishing a multiannual plan for the stocks of cod, herring and sprat in the 
Baltic Sea and the fisheries exploiting those stocks, amending Council Regulation (EC) No 2187/2005 and repealing Council Regulation (EC) No 1098/2007.

Grüss, A., Robinson, J., Heppell, S. S., Heppell, S. A., and Semmens, B. 2014. Conservation and fisheries effects of spawning aggregation marine protected areas: What we know, where we should go, and what we need to get there. ICES Journal of Marine Science, 71: $1515-1534$.

Halpern, B. S. 2003. The Impact of Marine Reserves: Do Reserves Work and Does Reserve Size Matter? Ecological Applications, 13: 117-137.

Hinrichsen, H. H., Möllmann, C., Voss, R., Köster, F. W., and Kornilovs, G. 2002.

Biophysical modelling of larval Baltic cod growth and survival. Canadian Journal of Fisheries and Aquatic Sciences, 59: 1858-1873.

Hinrichsen, H. H., Voss, R., Wieland, K., Köster, F., Andersen, K. H., and Margonski, P. 2007. Spatial and temporal heterogeneity of the cod spawning environment in the Bornholm Basin, Baltic Sea. Marine Ecology Progress Series, 345: 245-254.

Hinrichsen, H. H., Lehmann, A., Petereit, C., Nissling, A., Ustups, D., Bergström, U., and Hüssy, K. 2016a. Spawning areas of eastern Baltic cod revisited: Using hydrodynamic modelling to reveal spawning habitat suitability, egg survival probability, and connectivity patterns. Progress in Oceanography, 143: 13-25.

Hinrichsen, H. H., von Dewitz, B., Dierking, J., Haslob, H., Makarchouk, A., Petereit, C., and Voss R. 2016b. Oxygen depletion in coastal seas and the effective spawning stock biomass of an exploited fish species. Royal Society Open Science, 3: 150338.

Huwer, B., Clemmesen, C., Grønkjær P., and Köster, F. W. 2011. Vertical distribution and growth performance of Baltic cod larvae - Field evidence for starvation-induced recruitment regulation during the larval stage? Progress in Oceanography, 91: 382-396.

Huwer, B., Hinrichsen, H. H., Böttcher, U., Voss, R., and Köster, F. W. 2014. Characteristics of juvenile survivors reveal spatiotemporal differences in early life stage survival of Baltic cod. Marine Ecology Progress Series, 511: 165-180.

Hüssy, K. 2011. Review of western Baltic cod (Gadus morhua) recruitment dynamics. ICES Journal of Marine Science, 68: 1459-1471.

Hüssy, K., Hinrichsen, H. H., and Huwer, B. 2012. Hydrographic influence on the spawning habitat suitability of western Baltic cod (Gadus morhua). ICES Journal of Marine Science, 69: 1736-1743. 
Hüssy, K., Hinrichsen, H. H., Eero, M., Mosegaard, H., Hemmer-Hansen, J., Lehmann, A., and Lundgaard, L. S. 2016. Spatio-temporal trends in stock mixing of eastern and western Baltic cod in the Arkona Basin and the implications for recruitment. ICES Journal of Marine Science, 73: 293-303.

IBSFC. 1994. Proceedings of the International Baltic Sea Fisheries Commission $20^{\text {th }}$ session, Gdynia, Poland, 12-16 September 1994.

ICES. 2004. Report of the Study Group on Closed Spawning areas of Eastern Baltic cod. ICES Document CM 2004/ACFM: 17. Charlottenlund, Denmark.

ICES. 2018a. Report of the Baltic Fisheries Assessment Working Group (WGBFAS). ICES Document CM 2018/ACOM: 11. Copenhagen, Denmark.

ICES. 2018b. Report of the workshop to evaluate the effect of conservation measures on Eastern Baltic cod (WKCONGA). ICES Document CM CM/ACOM:51. Copenhagen, Denmark.

Kraus, G., Pelletier, D., Dubreuil, J., Möllmann, C., Hinrichsen, H. H., Bastardie, F., Vermard, Y., and Mahévas, S. 2009. A model-based evaluation of Marine Protected Areas: the example of eastern Baltic cod (Gadus morhua callarias L.). ICES Journal of Marine Science, 66: 109-121.

Köster, F. W., Möllmann, C., Hinrichsen, H. H., Tomkiewicz, J., Wieland, K., Kraus, G., Voss, R., et al. 2005. Baltic cod recruitment - the impact of climate and species interaction. ICES Journal of Marine Science, 62: 1408-1425.

Köster, F. W., Vinther, M., MacKenzie, B. R., Eero, M., and Plikshs, M. 2009. Environmental effects on recruitment and implications for biological reference points of eastern Baltic cod (Gadus morhua). Journal of Northwest Atlantic Fishery Science, 41: 205-220.

Köster, F. W., Huwer, B., Hinrichsen, H. H., Neumann, V., Makarchouk, A., Eero, M., Dewitz, B. V., et al. 2017. Eastern Baltic cod recruitment revisited—dynamics and impacting factors. ICES Journal of Marine Science, 74: 3-19.

Lester, S. E., Halpern, B. S., Grorud-Colvert, K., Lubchenco, J., Ruttenberg, B. I., Gaines, S. D., Airamé, S., et al. 2009. Biological Effects Within No-Take Marine Reserves: A global Synthesis. Marine Ecology Progress Series, 384: 33- 46.

MacKenzie, B. R., St. John, M. A., and Wieland, K. 1996. Eastern Baltic cod: perspectives from existing data on processes affecting growth and survival of eggs and larvae. Marine Ecology Progress Series, 134: 265-281. 
MacKenzie, B. R., Hinrichsen, H. H., Plikshs, M., and Wieland, K. 2000. Quantifying environmental heterogeneity: estimating the size for successful cod egg development in the Baltic Sea and its influence on recruitment. Marine Ecology Progress Series, 193:143-156. Marteinsdottir, G., and Steinarsson, A. 1998. Maternal influence on the size and viability of Iceland cod Gadus morhua eggs and larvae. Journal of Fish Biology, 52: 1241-1258.

Morgan, M. J., Wilson, C. E., and Crim, L.W.1999. The effect of stress on reproduction in Atlantic cod. Journal of Fish Biology, 54: 477-488.

Murawski, S. A., Brown, R., Lai, H.-L., Rago, P. J., and Hendrickson, L. 2000. Large-scale closed areas as a fishery-management tool in temperate marine systems: the Georges Bank experience. Bulletin of Marine Science, 66: 775-798.

Nielsen, E. E., Hansen, M. M., Ruzzante, D. E., Meldrup, D., and Grønkjær, P. 2003. Evidence of a hybrid-zone in Atlantic cod (Gadus morhua) in the Baltic and the Danish Belt Sea revealed by individual admixture analysis. Molecular Ecology, 12: 1497-1508.

Nielsen, E. E., Grønkjær, P., Meldrup, D., and Paulsen, H. 2005. Retention of juveniles within a hybrid zone between North Sea and Baltic Sea Atlantic cod (Gadus morhua). Canadian Journal of Fisheries and Aquatic Sciences, 62: 2219-2225.

Neumann, V., Köster, F. W., Schaber, M., and Eero, M. 2014. Recovery in eastern Baltic cod: is increased recruitment caused by decreased predation on early life stages? ICES Journal of Marine Science, 71: 1382-1392.

O’Keefe, C. E., Cadrin S. X., and Stokesbury, K. D. E. 2014. Evaluating effectiveness of time /area closures, quotas/caps, and fleet communications to reduce fisheries bycatch. ICES Journal of Marine Science, 71: 1286-1297.

Pastoors, M. A., Rijnsdorp, A. D., and Van Beek, F. A. 2000. Effects of a partially closed area in the North Sea ("plaice box") on stock development of plaice. ICES Journal of Marine Science, 57: 1014-1022.

Pendleton, L. H., Ahmadia, G. N., Browman, H. I., Thurstan, R. H., Kaplan, D. M. and Bartolino, V. 2017. Debating the effectiveness of marine protected areas. ICES Journal of Marine Science, doi:10.1093/icesjms/fsx154.

Plikshs, M., Hinrichsen, H. H., Elferts, D., Sics, I., Kornilovs, G., and Köster, F. W. 2015. Reproduction of Baltic cod, Gadus morhua (Actinopterygii: Gadiformes: Gadidae), in the Gotland Basin: Causes of annual variability. Acta Ichthyologica Et Piscatoria, 45: 247258. 
Poćwierz-Kotus, A., Kijewska, A., Petereit, C., Bernaś, R., Więcaszek, B., Arnyasi, M., Lien, S., et al. 2015. Genetic differentiation of brackish water populations of cod Gadus morhua in the southern Baltic, inferred from genotyping using SNP-arrays. Marine Genomics, 19: $17-22$.

Pomeroy, R. S., Watson, L. M., Parks, J. E., and Cid, G. A. 2005. How is your MPA doing? A methodology for evaluating the management effectiveness of marine protected areas. Ocean \& Coastal Management, 48: 485-502.

Roberts, C. M., Hawkins, J. P., and Gell, F. R. 2005. The role of marine reserves in achieving sustainable fisheries. Philosophical Transactions of the Royal Society B, 360: 123-132.

Russ, G. R., Alcala, A. C., Maypa, A. P., Calumpong, H. P., and White A. T. 2004. Marine reserve benefits local fisheries. Ecological Applications, 14: 597-606.

Russell, M. W., Luckhurst, B. E., and Lindeman, K. C. 2012. Management of spawning aggregations. In Reef fish spawning aggregations: biology, research and management, pp. 371-404. Ed. by Y. Sadovy de Mitcheson, and P. L. Colin. Springer, Berlin. 584 pp.

Sadovy de Mitcheson, Y, and Erisman, B. 2012. Fishery and biological implications of fishing spawning aggregations, and the social and economic importance of aggregating fishes. In Reef fish spawning aggregations: biology, research and management, pp. 225284. Ed. by Y. Sadovy de Mitcheson, and P. L. Colin. Springer, Berlin. 584 pp.

Sheaves, M., Baker, R., and Johnston, R. 2006. Marine nurseries and effective juvenile habitats: an alternative view. Marine Ecology Progress Series, 318: 303-306.

STECF. 2007. Evaluation of closed area schemes (SGMOS-07-03). https://stecf.jrc.ec.europa.eu/documents/43805/44876/07-09_SG-MOS+07-03++ Evaluation + of + closed + areas + II.pdf

STECF. 2010. Report of the Sub Group on Management Objectives and Strategies (SGMOS 10-06). Part e) Evaluation of multi-annual plan for Baltic cod. 18-22 October 2010, Vigo. Ed. by J. Simmonds, C. Zimmermann, M. Eero, J. Berkenhagen, A. Montova, and R. Nielsen. Publications Office of the European Union, Luxembourg. 176 pp. STECF. 2016. Special request for evaluating Baltic cod additional measures (STECF-16-23). doi:10.2788/684620. Publications Office of the European Union, Luxembourg.

Suuronen, P., Jounela, P., and Tschernij, V. 2010. Fishermen responses on marine protected areas in the Baltic cod fishery. Marine Policy, 34: 237-243. 
713 Torres-Irineo, E., Gaertner, D., de Molina, A. D., and Ariz, J. 2011. Effects of time-area

714 closure on tropical tuna purse-seine fleet dynamics through some fishery indicators.

$715 \quad$ Aquatic Living Resources, 24: 337-350.

716 Trippel, E. A. 1998. Egg size and viability and seasonal offspring production of young

717 Atlantic cod. Transactions of the American Fisheries Society, 127: 339-359.

718 Vallin, L., and Nissling, A. 2000. Maternal effects on egg size and egg buoyancy of Baltic

719 cod, Gadus morhua. Implications for stock structure effects on recruitment. Fisheries

$720 \quad$ Research, 49: 21-37.

721 van Overzee, H. M. J, and Rijnsdorp, A. D. 2015. Effects of fishing during the spawning

722 period: implications for sustainable management. Reviews in Fish Biology and Fisheries,

$723 \quad 25: 65-83$.

724 Vandeperre, F., Higgins, R. M., Sánchez-Meca, J., Maynou, F., Goñi, R., Martín-Sosa, P.,

725 Pérez-Ruzafa, A., et al. 2011. Effects of no-take area size and age of marine protected

726 areas on fisheries yields: a meta-analytical approach. Fish and Fisheries, 12: 412-426

727 Voss, R., Köster, F. W., and Dickmann, M. 2003. Comparing the feeding habits of co-

728 occurring sprat (Sprattus sprattus) and cod (Gadus morhua) larvae in the Bornholm Basin,

729 Baltic Sea. Fisheries Research, 63: 97-111.

730 Wieland, K. 1988. Distribution and mortality of cod eggs in the Bornholm Basin (Baltic Sea)

731 in May and June 1986. Kieler Meeresforschungen. Sonderheft, 6: 331-340.

732 Wieland, K., Jarre-Teichmann, A., and Horbowa, K. 2000. Changes in the timing of spawning

733 of Baltic cod: possible causes and implications for recruitment. ICES Journal of Marine

734 Science, 57: 452-464.

735 Zemeckis, D. R., Hoffman, W. S., Dean, M. J., Armstrong, M. P., and Cadrin, S. X. 2014.

736 Spawning site fidelity by Atlantic cod (Gadus morhua) in the Gulf of Maine: implications

737 for population structure and rebuilding. ICES Journal of Marine Science, 71: 1356-1365. 